\title{
THE EFFECT OF DREAM AND DOODLE BOOKS ON CHILDREN'S CREATIVE THINKING SKILLS
}

\author{
Arzu Akar Gençerii, \\ Abide Güngör Aytar ${ }^{2}$ \\ ${ }^{1}$ Kurklareli University \\ Health High School, \\ Department of Child Development, \\ Kırklareli, Turkey \\ ${ }^{2}$ Gazi University, \\ Faculty of Education, \\ Department of Child Development and Education, \\ Ankara, Turkey
}

\begin{abstract}
:
This study aimed to examine the effectiveness of dream and doodle books in developing children's creative thinking skills. In the study, the case study, which is a qualitative research method, was used. A total of 13 children, 6 girls and 7 boys aged 6-9, were selected through purposive sampling. For three months, a total of thirty-two pages of painting completion activities were held with each child by using dream and doodle books three times a day each week. "The Torrance Test of Creative Thinking" is used as a data collection tool to evaluate the creative thinking skills of children. Content analysis was used as the analysis method. The rate of seeing the Creative Strengths in the posttest (Torrance Test of Creative Thinking Form B) drawings of the children was higher than the pre-test (Torrance Test of Creative Thinking Form A) drawings. When the pre-test and post-test results of Creative Strengths are examined, it is seen that there is the most difference in favor of the post-test in the "Movement and Action and Storytelling Articulateness" aspects. The aspect with the least difference is "Synthesis of Lines and Circles". The dimension that has never been seen in children's drawings has been "Synthesis of Incomplete Figures". It was concluded that Dream and Doodle Books improve children's creative thinking skills. Dream and Doodle books are artistic studies that allow children to express themselves in different ways. In this context, it is recommended that teachers and families include these books in their activities.
\end{abstract}

Keywords: creative thinking skills, preschool art activity, creativity, early childhood

i Correspondence: email arzu.akar1@gmail.com 


\section{Introduction}

In recent years, creative thinking has become an important skill in adapting to the changing world. Creative thinking is a feature found at different levels in every individual (Runco, 2004). Also, creative thinking skills expressed as the ability of people to look from different perspectives, being able to go beyond the given information and the boundaries, thinking outside the traditional ways, doing something original, bringing together what seems unrelated to create something new (Torrance \& Goff, 1989).

Creative thinking skills also mean establishing relationships between different areas of learning and using knowledge and skills to bring ideas together in new and different ways. It includes many skills such as flexible imagination, generating new ideas, and problem-solving. Especially in the early childhood period, which includes the first years of human life, rich experiences that affect the creative thinking skills of children have a significant effect on brain development (Thornton \& Brunton, 2010). Children are curious, ask questions, observe, experiment, discover, and thus make new connections in their minds. These connections enable children to establish a relationship between old and new experiences (Isbell \& Raines, 2012). In this context, supporting children's creativity in the early childhood period when their creative potential is at a high level is crucial.

Creativity is at the center of all learning experiences for children. Diversified rich experiences, space and time to explore materials, freedom to try new things and solve problems, and opportunities to think flexibly and develop skills are important for children to develop their creativity (Thornton and Brunton, 2010).

Reggio Emilia, one of the alternative educational approaches, has adopted art and creativity education as philosophy. Loris Malaguzzi, the founder of the Reggio Emilia approach, frequently emphasized that all children are naturally creative and should have opportunities to develop their creative abilities and expressions. Malaguzzi attached great importance to children's self-expression methods and advocated the view that children develop their creativity by speaking, singing, dancing, painting, drawing, dramatizing, playing and using many other expressions (Thornton \& Brunton, 2010).

The impact of artistic activities on the promotion of creativity in childhood and the development of children's learning abilities is enormous. These activities improve children's skills of analysis (separating the components to understand the structure, seeing the similarities and differences), synthesis (creating a new structure by bringing the pieces together), and evaluation (evaluating the product according to certain measures). Children have the opportunity to express their feelings and thoughts through various expressions and symbolic environments. In their minds, they create imaginary drawings and ideas connected to them. Then they try to share them with the external world in different ways. Activities that bring together open-ended artistic activities for children on different subjects that are integrated with each other are very effective in the development of creativity (Valentini, 2002).

Edwards and Springate (1995) explain the required conditions for children to show their creativity in the classroom environment under the subheadings of time, place, 
material, climate, and situations. As a result of many studies on creativity education applied to these components (Dziedziewicz, Gajda \& Karwowski, 2014; Garaigordobil \& Berrueco, 2011; Graigner, 2004; Kaytez \& Aytar, 2016; Isaksen \& Parnes, 1985; Tomlison \& Maples, 2000; Rose \& Lin, 1984; Zachopoulou, Trevlas, Konstadinidou \& Archimedes Project Research Group, 2006), it has been observed that children's creative thinking skills can be developed through education and that there is an increase in creative thinking skills in children. According to Pagani, Rubenso, and Runca (2003), creative activities offered to children in the preschool period support children's creative personality traits and creative thinking skills.

Educational programs that improve children's creative thinking skills include many different techniques. Artistic techniques such as music, drama, collage, and painting are used. While dealing with art, children both think and experience affective processes. Artistic works enable children to think, feel and find symbols to express themselves about their experiences and ideas (Aral \& Duman, 2014). Creative programs help children to paint, build, role play, move, sing, reveal their creativity with many expressions and develop creative thinking skills (Thornton \& Brunton, 2010).

This study aimed to examine the effectiveness of Dream and Doodle books in developing children's creative thinking skills. By using the drawings in Dream and Doodle books, adding to the stimulus in the books, narrating them, reconstructing their ideas, they created brand new products and thus had the opportunity to support their creative thinking skills. "Dream and Doodle" books (Catlow, 2009) aim to stimulate imagination and creative thinking. Children are encouraged to make creative drawings with the instructions given in these books for preschool and primary school children. With the effect of Dream and Doodle books, children's curiosity and motivation increase, also children's creative thinking skills are supported (Finke, Ward \& Smith, 1992).

\section{Material And Methods}

\subsection{Research Pattern}

In this study, one of the qualitative research methods, the case study was used. The case study involves organizing data according to specific situations to try to understand a situation holistically and contextually and to make an in-depth comparison (Patton, 2014).

\subsection{Research Group}

The study group of the research consists of seven girls and six boys at a total of thirteen volunteers between the ages of 6-9, who study at schools affiliated to Kirklareli Directorate of National Education, which are selected through easily accessible sampling method one of the purposeful sampling methods.

\subsection{Studying with Children and Ethics}

Concerning the decision-making of children's participation in research processes, attention should be paid to obtaining children's views. In Article 12, the qualifications of 
all processes where children are listened to and attended are specified by the Committee on the Rights of the Child (2009). Everyone involved in the research should benefit from the same ethical principles. A "symmetrical approach" should be adopted in terms of all principles, from obtaining the consent of children themselves (Morrow \& Richards, 1996), informing children about research, and applying participatory methods for children (Christensen \& Prout, 2002). This study adopted the image of participating children, and they were seen as social actors during the research process. When children are seen as social actors and have equal rights like other participants in the research, it will be possible to understand the world of children and to make their voices heard (Woodhead, 2004; Christensen \& Prout, 2002; Punch, 2012; Spyrou, 2011).

In this context, during the research process, apart from the informed consent of the parents, the children were informed about the study, and also informed consent was obtained from the children who volunteered. During all the processes, the children were informed about being able to leave the study at any time. The children were briefly informed about the study process, and the questions that the children were curious about were answered before the study process. In this way, it is aimed to make children feel that they are part and participants of the study. Also, the "Mosaic Approach" suggested by Clark and Moss (2001) was adopted in the study, and children were enabled to express themselves through drawing by using the drawing activity, which is a participatory method for children.

\subsection{Data Collection Tools}

\subsubsection{The Torrance Test of Creative Thinking}

The Torrance Test of Creative Thinking Test A and B equivalent forms were used as data collection tools. The purpose of the test is to evaluate children's creative thinking skills. The activities in the formal A-B equivalent forms are shaped in four dimensions based on the creative processes listed as fluency, flexibility, originality, and detail. The Turkish version of the scale was made by Aslan (2001), which was developed by Torrance in 1966. The test consists of two parts, Verbal and Figural. A and B are used to support each other because these forms have equivalent qualities in terms of Creative Thinking Dimensions.

\subsubsection{Dream and Doodle Books}

Dream and Doodle Books were studied during the research process. Dream and Doodle Books consist of different types developed by Catlow (2012) to increase the "Creative Thinking Skills" of children, such as Doodle Design \& Draw, and Fabulous Doodle 1-2-34. On the pages of these books, there are some drawings and sentences such as, "Where is this voice coming from? What's inside the cave? What came out of it when you opened the box?". Children can create a composition by completing these open-ended questions, inspired by the drawings on the page and complementing stimulating drawings and sentences with lines as they wish. Children can paint the drawings they have completed, and they can also title them. In this study, from different books, 32 activity pages were used, considering the developmental characteristics of the children. The selected activity pages were given to the children, by increasing the number of children. 


\subsection{Data Collection}

In this study, Equivalent Figural forms of The Torrance Test of Creative Thinking were used in the data collection process. The A and B forms, which have equivalent test features, consist of three activities: drawing, identifying pictures, and parallel lines. In the pre-test and post-test stages, applications were carried out with children for two weeks. The research was carried out in Kirklareli University Game Room. Drawing exercises were carried out with the children once a week for three months with Dream and Doodle Books.

It was thought that it would be appropriate to conduct individual studies to prevent children from being affected by each other. In each study session, three activity sheets were given to the children, and the drawings were completed. On the activity pages, there are some texts and images that contain different stimuli such as, "What's in the box? What is the bird lover man watching?, Whose houses are these? What's this issue? What's that sound?". "There is a drawing, shape, and line in this page. You can complete this drawing in an interesting and different way by adding lines to them as you wish. Think of a drawing that no one would think of. By adding new ones to your first idea, you can make your drawing tell a different and interesting story as you can. When you complete your drawing, think of a name or a title for it, and it should be the name and title that describe your drawing best." instructions are given to children.

\subsection{Reliability}

In terms of reliability, the opinion of a field expert who received "The Torrance Test of Creative Thinking" was also obtained, and the pre-test and post-test data were evaluated. During the evaluation process, support was received from a research assistant who receives "The Torrance Test of Creative Thinking" and works on creativity in the preschool field. Thus, the reliability of the data was tested and was tried to be provided. The reliability of the study was determined as .90. In qualitative research, it is crucial to ensure the originality and credibility of the findings. Therefore, it was deemed appropriate to use the "Reliability = Consensus / Consensus + Disagreement" formula developed by Miles and Huberman (1994). The validity of qualitative research is ensured by presenting the collected data with a richness of imagery. Internal validity, on the other hand, is ensured by the presentation of the results clearly, the comprehensibility of the results by the readers, and the original portrait of the researched subject (Miles \& Huberman, 1994).

Equivalent tests are used as effective methods to provide reliability (Ercan \& Kan, 2004). Besides, to increase the reliability, A form was used as the pre-test and B form as the post-test.

\subsection{Analysis of Data}

"The Torrance Test of Creative Thinking" can be evaluated in two stages as "aspects of creativity" and "13 checklists of creative strengths". In this study, the evaluation was made according to the "13 checklists of creative strengths". The Checklists of Creative Strengths contains the following aspects: Emotional Expressiveness, Storytelling 
Articulateness, Movement and Action, Abstractness of Titles, Synthesis of Incomplete Figures, Synthesis of Lines and Circles, Unusual Visualization, Internal Visualization, Extending and Breaking Boundaries, Humor, Richness of Imagery, Colorfulness of Imagery, and Fantasy. 13 Checklists of Creative Strengths formed the categories of the study. Which of these 13 aspects were seen in the children's drawings, and their frequency was examined. The data were evaluated with content analysis. Basically, in content analysis, similar data and certain categories are brought together within the framework of themes then organized and interpreted in a way that readers can understand (Yıldırım \& Şimşek, 2006).

\section{Results}

In this section, the findings and comments regarding the "13 Checklists of Creative Strengths" applied to children before and after the Dream And Doodle Books Study have been discussed.

Table 1: Pre-test and Post-test Results of 13 Checklists Of Creative Strengths

\begin{tabular}{lcc}
\hline Creative Strengths & Pre-test (n) & Post-test (n) \\
\hline Emotional Expressiveness & 20 & 25 \\
\hline Storytelling Articulateness & 11 & 17 \\
\hline Movement and Action & 10 & 18 \\
\hline Abstractness of Titles & 8 & 11 \\
\hline Synthesis of Lines and Circles & 0 & 1 \\
\hline Synthesis of Incomplete Figures & 0 & 0 \\
\hline Unusual Visualization & 7 & 10 \\
\hline Internal Visualization & 3 & 7 \\
\hline Extending and Breaking Boundaries & 10 & 15 \\
\hline Humor & 4 & 7 \\
\hline Richness of Imagery & 5 & 7 \\
\hline Colorfulness of Imagery & 4 & 6 \\
\hline Fantasy & 10 & 12 \\
\hline
\end{tabular}

Torrance Test Creative Power Checklist results applied to children before and after the Dream and Draw Books Study are shown in Table 1. Except for the Synthesis of Incomplete Figures, 12 aspects of the 13 Checklists Of Creative Strengths were seen in the test results in pre-test and post-test evaluations.

In the post-test $(n=136)$ evaluations of the children, the rate of seeing Creative Strengths is higher than the pre-test $(n=92)$ drawings. The greatest difference in pre-test and post-test aspects was observed in "Movement and Action (pre-test $\mathrm{n}-11$, post-test $\mathrm{n}=$ 18)" and "Storytelling Articulateness (pre-test $n=10$, post-test $n=18$ )", while the least difference was observed in "Synthesis of Lines and Circles (pre-test $n=0$, post-test $n=$ $1)^{\prime \prime}$.

The incidence of the "Emotional Expressiveness" aspect is 20 in the pre-test and 25 in the post-test. "Storytelling Articulateness" was seen 11 times in the pre-test and 17 times in the post-test. "Movement and Action" was seen 10 times in the pre-test and 18 
times in the post-test. "Abstractness of Titles " was seen 8 times in the pre-test and 11 times in the post-test. "Synthesis of Lines and Circles" was seen in only 1 child's drawing in the pre-test, while the "Synthesis of Incomplete Figures" was not encountered in the drawings in the pre-test and post-test. "Unusual Visualization" was seen 7 times in the pre-test and 10 times in the post-test. "Internal Visualization" was seen 3 times in the pretest and 7 times in the post-test. "Extending and Breaking Boundaries" was seen 10 times in the pre-test and 15 times in the post-test. "Humor" was seen 4 times in the pre-test and 7 times in the post-test. "Richness of Imagery" was seen 5 times in the pre-test and 7 times in the post-test. "Colorfulness of Imagery" was seen 4 times in the pre-test and 6 posttests in the pre-test. "Fantasy" was seen 10 times in the pre-test and 12 times in the posttest.

\subsection{Interpretation of Findings Regarding Emotional Expressiveness}

"Emotional Expressiveness" is defined as expressions such as making figures talk ( like I am sorry), exclamation marks attributed to the title with headlines, facial expressions, body movements or body positions, personalizing animals or objects, and drawn expressions to show good feelings such as pride and success (Institute of Gifted, 2013). Children personalized living and inanimate beings with expressions in their drawings such as beautiful flower, wavy sea, cute alien car, smiling face, dancing crab, arrogant hedgehog. Expressions such as a flying robot, a dog with a raised ear were also evaluated in the "Emotional Expressiveness" category by examining the relationship between body positions and the title.

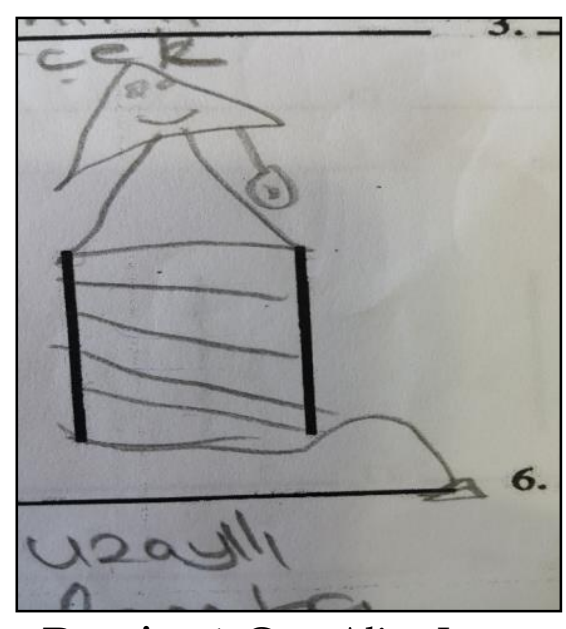

Drawing 1: Cute Alien Lamp

(Defne, 8)

Since the drawings in dream and doodle books are frequently discussed on feelings like "How Does It Feel, Why Excited, Why Scared" with children, it is thought that children use emotional descriptions more intensely in their post-test drawings. Drawing is the most natural image of the emotional and intellectual life of the child, which is expressed originally and plainly. Some lines, symbols and signs that children acquire through perception are very meaningful in terms of the activity process and can 
be seen as important elements that reflect their world directly, plainly and purely (Artut, 2002). Malchiodi (1998) states that children reveal their thoughts, feelings, events and world views by telling about their drawings.

\subsection{Interpretation of Findings Regarding Storytelling Articulateness}

The "Storytelling Articulateness" aspect is defined as going beyond simple drawing by adding verbal or figural details such as subject, environment, relationships, place, time and history, and the existence of a relationship between an implied story or objects (Institute of Gifted, 2013 ).

In the sample drawings given in drawing 2 and 3, children detailed their drawings with sentences such as the crazy snail had eaten all the grass in the garden and other animals tried to catch it, and a horse with banana feet and cheese wings went out to travel around the world and those who saw it were very surprised.

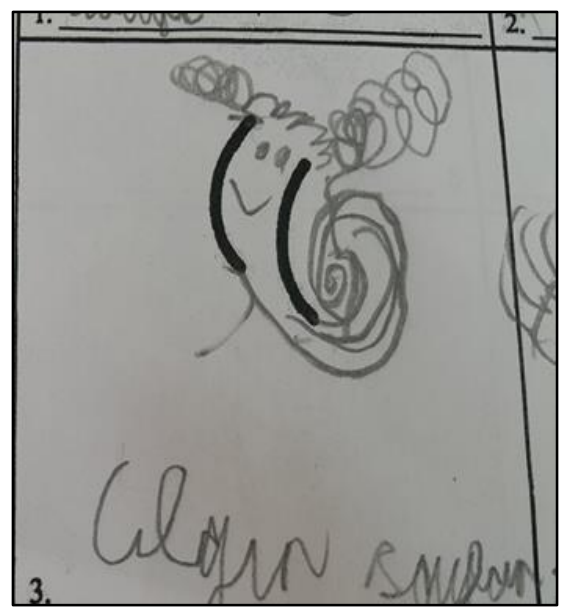

Drawing 2: Snail

(Yeşim, 9)

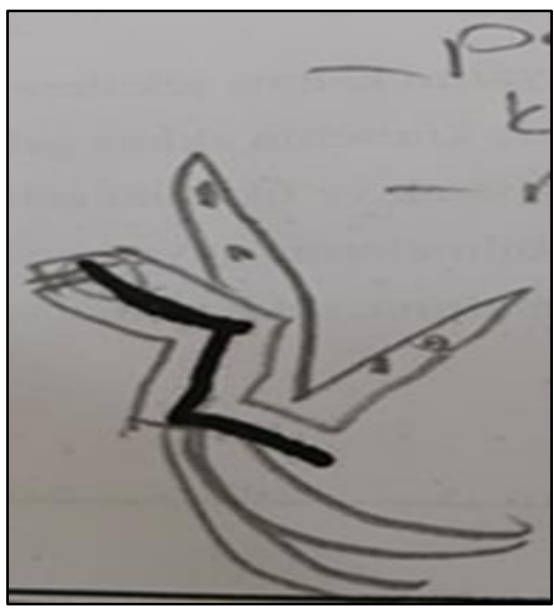

Drawing 3: Cheese Winged Banana Footed Horse (Defne, 8)

It is thought that the stimulating drawings in Dream And Doodle Books have a supportive effect on children to narrate their drawings. Stimulating questions such as "What's in this box?" and "Whose teeth are these?" are an incentive for children to start and continue a story. The narrative skill supports children's language and cognitive skills. These two basic skills converge at the point of children's creativity. When children talk on drawings and narrate drawings as imaginations, they have the opportunity to develop creative thinking, conceptualizing, establishing relationships between concepts, events, objects, and multi-dimensional thinking skills, while at the same time developing their ability to have the command of a language, establish semantic relationships, and use language effectively (Boudreau, 2007). While children are painting, they narrate and construct it in a holistic composition. Painting is also a mental composition and offers children the opportunity to express their feelings and thoughts (Machioldi, 2005). 


\subsection{Interpretation of Findings Regarding Movement and Action}

The "Movement and Action" aspect of the Torrence Creative Strengths is defined as movement lines, action-hinted title, body posture, and animation that help to express movement (Institute of Gifted, 2013). Usually, movements such as running, flying, dancing, scuba diving, fighting, skiing, throwing, bending, hitting, eating, drinking, swimming is frequently used. It could be human figures with arms raised, knees bent, feet raised, or a bird in the air, a bird with its wings spread, water flowing from the faucet. In the sample drawings in Drawings 4 and 5, it was seen that they added movement to their paintings with expressions such as Flying Caravan, Dancing Crab, Closed Flower. It is thought that the increase in the pre-test and post-test drawings of children in favor of the post-test encourages the Storytelling Articulateness of Dream And Doodle Books for objects and actions. It is often seen that children of this age focus their imaginations on objects and animals and also personify them(Halmatov, 2016).

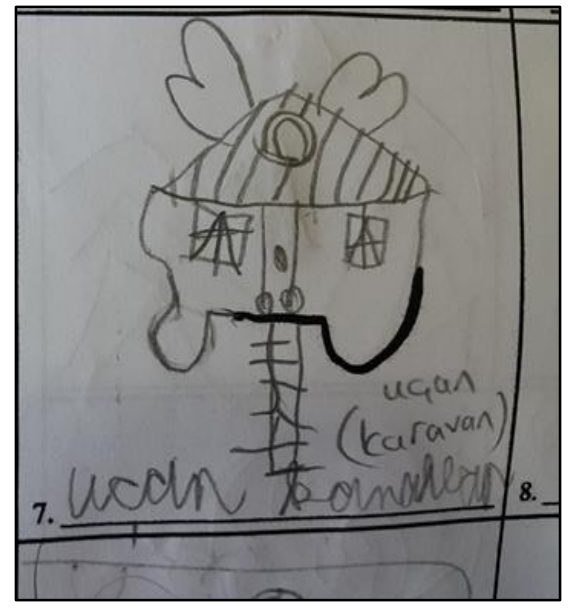

Drawing 4: Flying Caravan

(Deniz, 7)

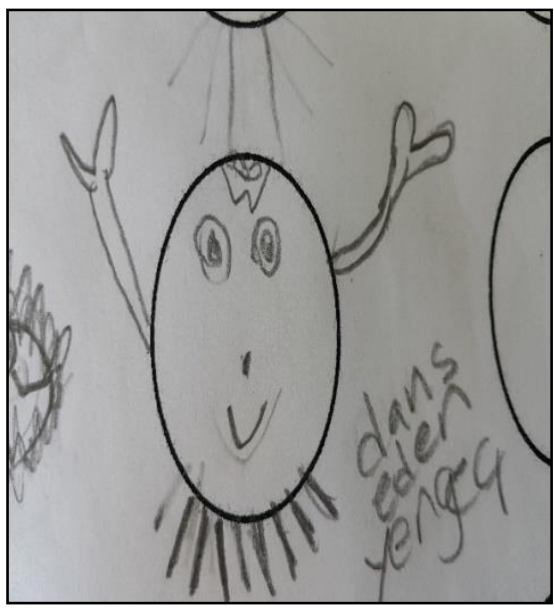

Drawing 5: Dancing Crab

(Mert, 8)

\subsection{Interpretation of Findings Regarding The Abstractness of Titles}

The Abstractness of Titles aspect includes descriptive and captions explaining what the drawing is.

Cautionary titles such as "Whose houses are these?" take place in Dream And Doodle Books. While the titles and the drawings waiting to be completed encourage children to make a story, they also allow them to draw according to the title. It has also been supportive of children in defining titles suitable for their drawings. These studies provide children the opportunity to describe their drawings with appropriate titles. Children must be supported to establish a semantic relationship between events, objects, situations, and to reflect the drawing as a whole by naming them to support their language skills (Machioldi, 2005). 


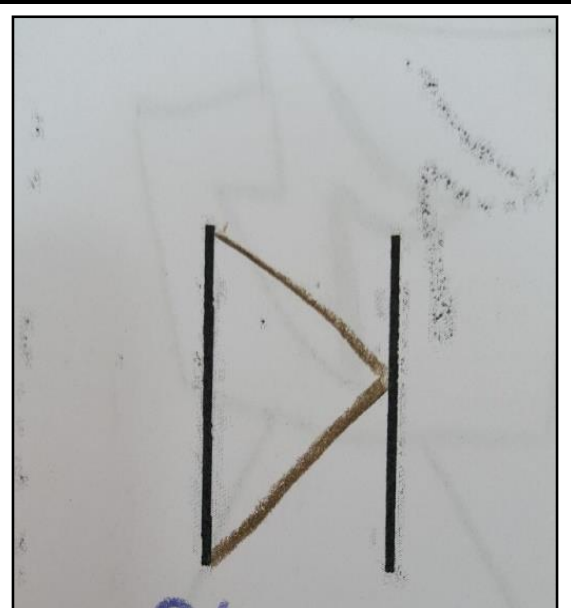

Drawing 6: Arrow: Showing Direction (Nazl1, 9)

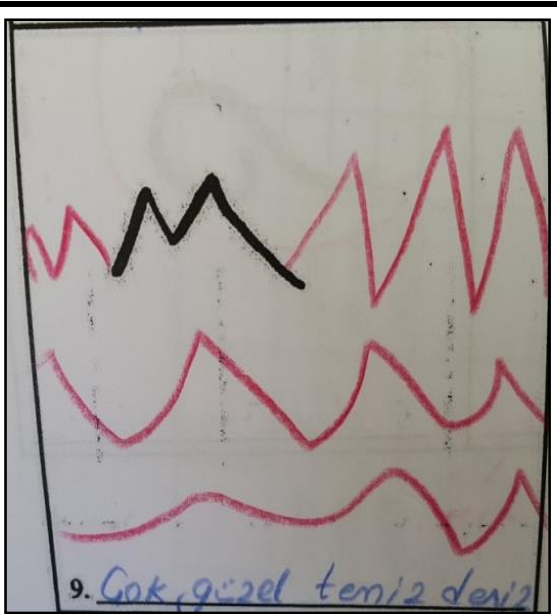

Drawing 7: Very Nice Clean Sea

(Hakan, 6)

\subsection{Interpretation of Findings Regarding Synthesis of Lines and Circles}

Synthesis of Lines and Circles aspect includes combinations of shapes.

It is scored only in Activity 3 of the Thinking Test. In the drawing given as an example in Drawing 8, 3 figures are combined and described as "the road to Istanbul". Synthesis of Lines and Circles is not common. While children generally perceive the shapes separately, some children combine the shapes originating from the ability to interpret the shape more holistic. While this situation develops within the framework of children's visual perception and cognitive development, it is also related to creative thinking skills such as looking from a different perspective (Tuğrul et al., 2001).

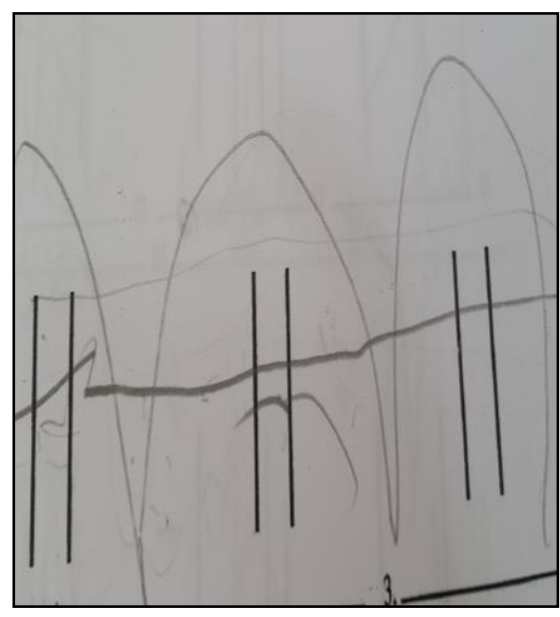

Drawing 8: The Road to Istanbul

(Hakan, 6)

\subsection{Interpretation of Findings Regarding Synthesis of Incomplete Figures}

Synthesis of Incomplete Figures aspect takes place only in Activity 2 of the Torrance Creative Thinking Test. It means that the figures are interrelated and the compositional use of multiple figures together (Institute of Gifted, 2013).

This aspect was not seen in the pre-test and post-test drawings of the children and is one of the characteristics seen in children with divergent thinking skills. Guilford (1984) 
generally states that individuals have two types of thinking dimensions. One of these defined as convergent thinking is the logical and linear thinking aspect, based on wellknown answers and focused on the only correct answer. The other is the aspect of divergent thinking means generating original and extraordinary ideas based on many possibilities. In the development of high-level thinking skills of children, they need to produce divergent thinking. Differences, variations, possibilities, perspectives, options, metaphors, connections, and imagination are possibilities to feed divergent thinking.

\subsection{Interpretation of Findings Regarding Unusual Visualization}

The Unusual Visualization aspect is to draw a shape from a different perspective than its common and usual view. Differently, it is defined as details such as distance to objects, inversion, positioning face down, adding size or depth.

It can be stated that the stimulating drawings in Dream and Doodle Books encourage children to think from a visual perspective. For example, in the drawing "You Opened The Box and What's Inside?" there is a child positioned upside down on the page and seen in the position of looking at the box from above. These stimulating drawings allow children to develop their visual perspective skills (Kindap \& Sayıl, 2005).

In the drawings given in Drawings 9 and 10, "Girl Looking From Side and Symmetry Board" is an example of using visual perspective.

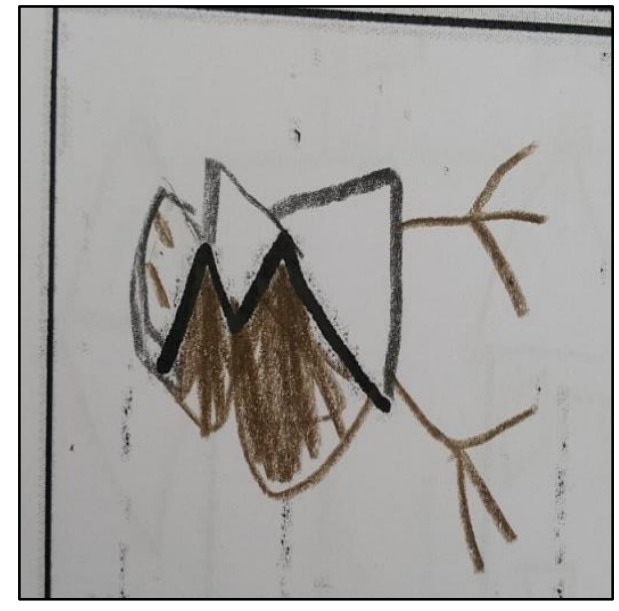

Drawing 9: Girl Looking From Side $($ Nazl1, 9)

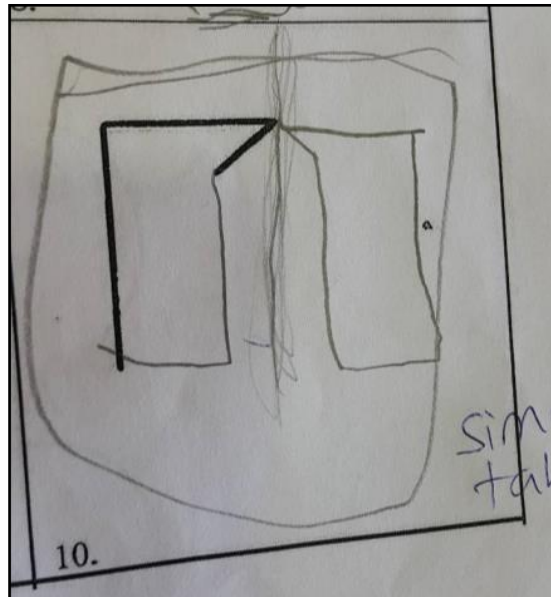

Drawing 10: Symmetry Board (Mert, 8)

\subsection{Interpretation of Findings Regarding Internal Visualization}

Internal Visualization aspect is defined as showing one thing in another such as seeds under the ground, worms, seed drawings showing the sprouting of the plant, aquarium or lake, fish in the sea, fire from a dragon's mouth and potatoes in a sack.

It is thought that the difference seen in the pre-test post-test drawings of children in favor of the post-test is that the dream and doodle books encourage children to interpret the drawings containing stimuli in the books from a perspective and that the children develop their perspective on internal perspective. Children use a range of cognitive skills such as understanding and comprehending from object and figure 
drawings, understanding and expressing the relationship of direction, being able to rotate in mind, and also finding a place-direction in space. Supporting children with activities such as playing and painting has an important role in the development of these skills (Newcombe \& Frick, 2010).

In Internal Visualization, in terms of visual perception, it has been seen that the main character of the painting is expressed as invisible when viewed from the outside and perceived as inside. For example, in Drawing 11, which is expressed as the Snake Remaining in the Nest, the area specified as the nest of the snake was clearly drawn as the border area, and the snake was represented inside as the letter Y. In Drawing 12, while the turtle is clearly represented with lines, it is reflected with a closed (invisible) representation with the depiction that its head is inside.

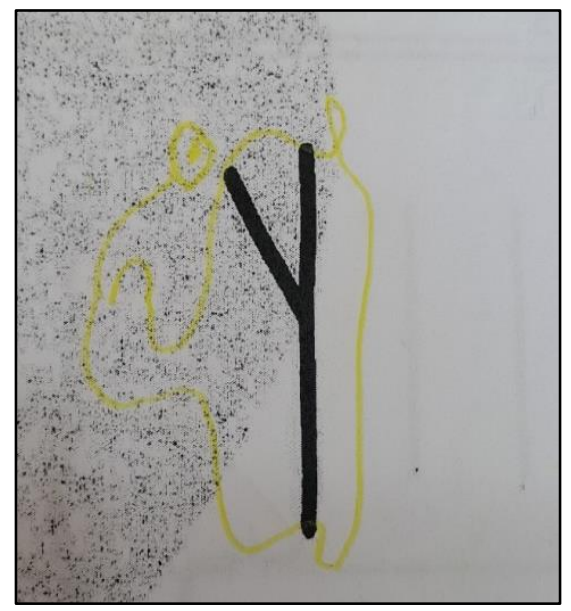

Drawing 11: Snake Remaining in the Nest (Belis, 9)

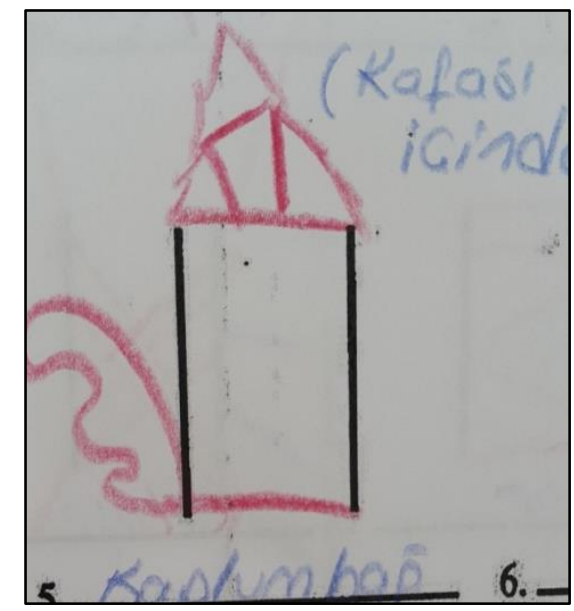

Drawing 12: Turtle With Head Inside (Deniz, 7)

\subsection{Interpretation of Findings Regarding Extending and Breaking Boundaries}

Extending and Breaking Boundaries aspect refers to drawings such as extending lines up, down, or out, using the rectangle in half, extending the lines up or out, cutting the circle to add depth, etc.

It can be said that the difference observed in children's pre-test and post-test drawings in favor of the post-test, children's regular participation in drawing completion activities for 3 months, and the completion and integration of the stimulus drawing activities in dream and doodle books helped children to develop their skills of using lines in different ways. Extending and breaking boundaries aspect develops with the cognitive skills of children, and in this way, children gain different dimensions to objects and shapes. It contributes to supporting children's drawing skills and developing their perspective and visual perception on shapes and drawings (Kindap \& Sayıl, 2005). 


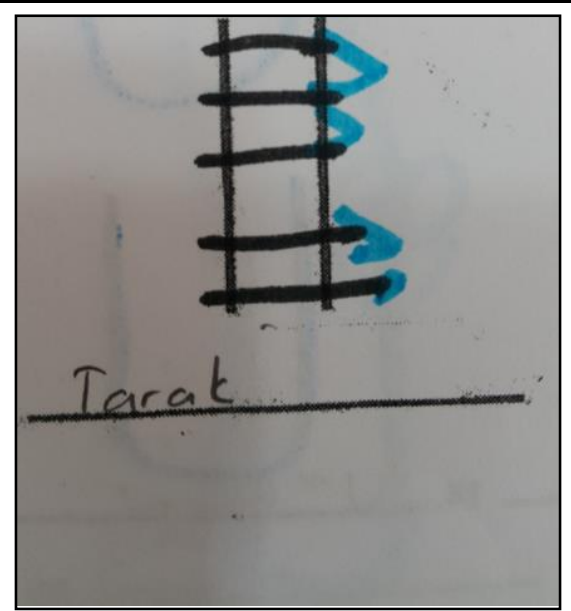

Drawing 13: Comb (Ali, 9)

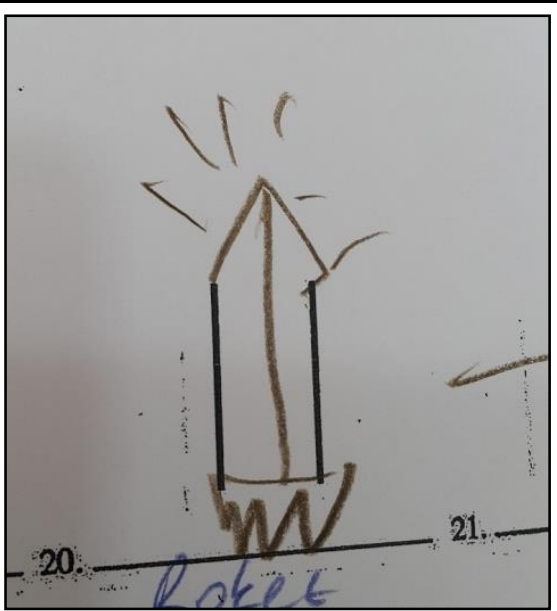

Drawing 14: Rocket

(Selin, 6)

\subsection{Interpretation of Findings Regarding Humor}

Humor aspect is defined as wordplay, satire, absurdity, ridiculousness, strangeness, drawings with exaggeration, word arts, games, hidden connections or expressing something like the opposite, teasing-mocking, speech bubble, or expressions written in quotes to indicate that the joke was made.

In terms of research findings, it is thought that the increase in humor aspect in favor of the posttest may be due to the fact that the stimuli in the Dream and Doodle Books contain humor elements. Such drawings like "Pull me out! Where does this smell come from?, We are surrounded!" encourages children to use the humor category in their paintings. Children making a human face to the flower and the sun and decorating the chimneys of the houses with different figures is due to the humorous feature (Yavuzer, 2007). Humor contributes to the development of analytical thinking and problem-solving skills in children. Thinking and questioning the relationship between conflict and incompatibilities within a joke, riddle, or humorous event contributes to this skill of most (McGhee, 2002). Having a good sense of humor is very important in establishing positive interpersonal relationships (Morreall, 1997).

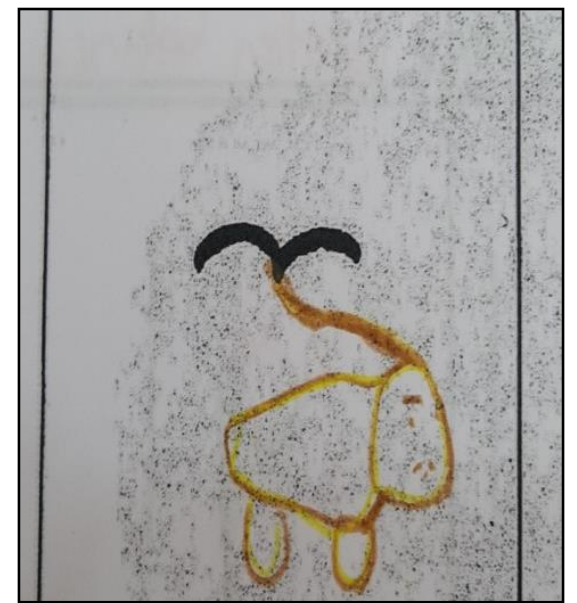

Drawing 15: Dog With Ear In The Air (Sude, 8)

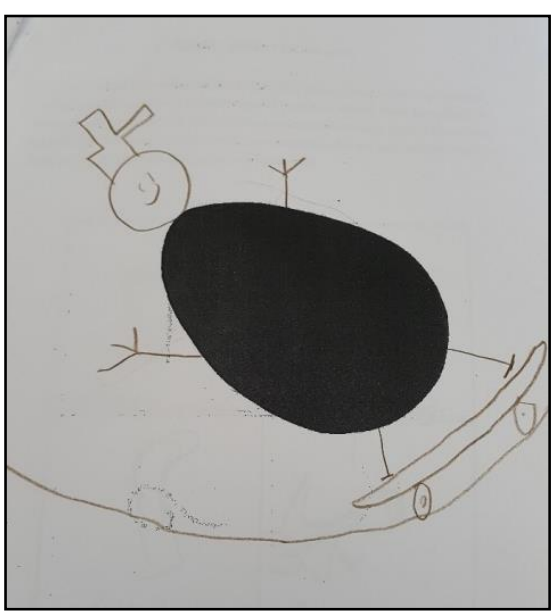

Drawing 16: Look At The Skateboarder! (Ali, 9) 


\subsection{Interpretation of Findings Regarding Richness of Imagery}

The Richness of the Imagery aspect is defined as the details that children add depth, color, and dimension to their drawings to fill them in and add color.

It is thought that the increase in favor of the posttest for the richness of the imagery is because children have had the opportunity to enrich their paintings by making additions by inspiring from unfinished drawings in the Dream and Doodle Books.

Drawing 17 "Arrogant Hedgehog" is an example of the richness of the imagery aspect.

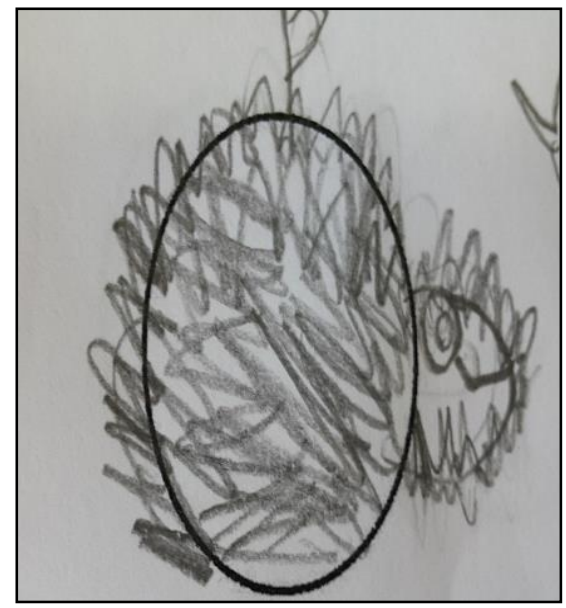

Drawing 17: Arrogant Hedgehog

(Deniz, 7)

\subsection{Interpretation of Findings Regarding Colorfulness of Imagery}

The Colorfulness of the Imagery aspect expresses the senses and emotions reflected in the drawing. They appeal to sensory organs other than sight (taste, smell, touch, hearing). They are imaginary and emotionally striking drawings that are not real and contain bodily animation. Religious, mythological, and fantastic drawings (ghosts, angels, devils, magic carpets, jugglers, mermaids, circuses, creatures, magic foods, etc.) are defined as drawing fantastic characters in literature or mythology.

In the study, when we look at the significance of the findings regarding the colorfulness of the imagery in favor of the post-test, it is stated that stimulating drawings in Dream and Doodle Books such as "Where does this sound come from?, What is this smell?, Whose feet are these?" improve children's skills related to the colorfulness of imagery in their drawings. Depending on their imagination and creative potential, children make various descriptions with drawings. Sensory representations are added to express descriptions better and to add more meaning to them. Children's animistic thinking (animation) skills enable them to load living features on inanimate objects. This situation is also related to children's creative thinking skills. Although children can distinguish between imagination and reality from the age of 3, creative and animistic expressions are seen in their paintings through their creative thinking skills (Leslie, 1987; Piaget, 1977). 


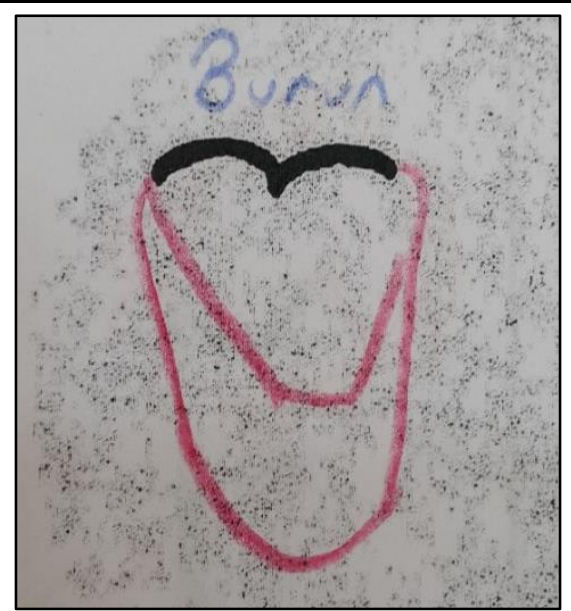

Drawing 18: The Nose Smells (Selin, 6)

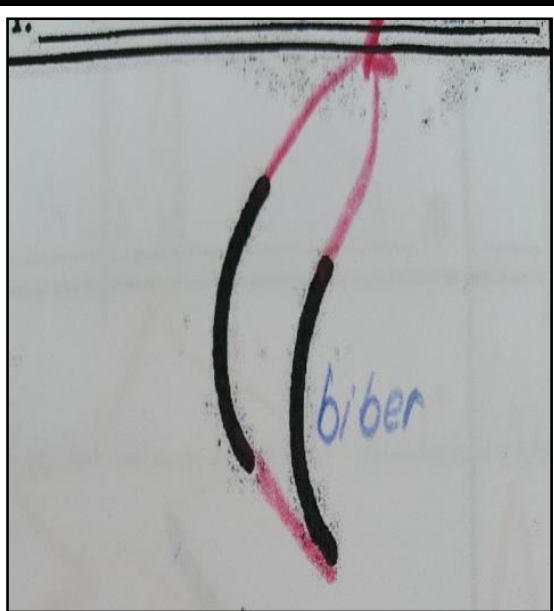

Drawing 19: Chili Pepper (Miray, 7)

\subsection{Interpretation of Findings Regarding Fantasy}

The fantasy aspect defines expressions as fictional characters (cartoons, fairy tales, myths, science fiction, etc.) from movies, books, television, or personification of living and inanimate objects (talking dog, laughing sun, etc.).

Children mostly use imaginary items in their paintings. In this age group, children use imaginary and symbolic game genres intensively, and also fairy tales and cartoon characters have a significant place in their imaginations. Dream and Doodle Books are thought to support children's ability to create imaginary characters and imaginary items. Singer and Singer (1990) defined childhood as the most intense period of imagination. The children's games, drawings, and stories they tell reflect their imaginations. Imagination has an important place in many areas of cognitive development such as language, hypothetical and flexible thinking, theory of mind skills, creative thinking, problem-solving, and executive function skills. In primary and middle childhood, children enjoy creating imaginary worlds and heroes. They can construct fictions such as language, currency, and management style of this special world (Tahiroğlu, 2016).

The "Secret Agent" drawing given in Drawing 20 is an example of imagination.

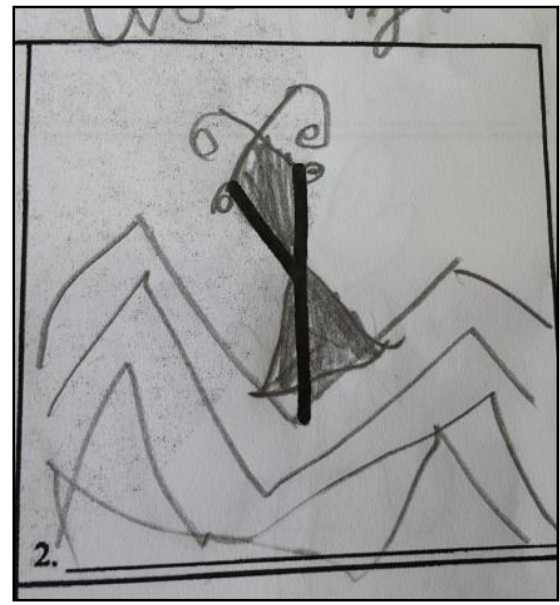

Drawing 20: Secret Agent

(Tanju, 9) 


\section{Recommendations}

Dream and Doodle Books are an exemplary technique that allows children to express themselves in different ways. It is suggested that teachers and families can do interactive studies by including the activities of the children. In this context, teachers and families can do interactive studies by including these books in children's activities. Besides, by bringing Dream and Doodle Books together with different age groups, researchers can make examinations depending on different variables such as gender and socioeconomic status and make scientific studies.

\section{Discussion and Conclusion}

In the study, which examines the effect of Dream and Doodle Books on children's creative thinking skills, it was observed that Dream and Doodle Books supported children's creative thinking skills within the framework of the Checklists Of Creative Strengths pretest and post-test results. In the pre-test and post-test results, it was seen that 12 aspects of the Checklists Of Creative Strengths were seen, while the Synthesis of Incomplete Figures aspect was not included in the pre-test and post-test evaluations. In this context, it is thought that Dream and Doodle Books are effective in the development of creative thinking skills.

Another important result is that children's skills about how to use a stimulus have been developed. Children were allowed to create a whole from parts and create a compositional product with open-ended questions, shapes, and drawings. In this respect, apart from structured toys, games, or materials, the study is seen as an important result in terms of open-ended and different thinking and bringing children together with studies where they can create original additions and produce products. In order to develop their creativity and imagination, they especially need materials that they can use freely and adapt as they want. Children who play with loose parts rather than structured games use their imaginations and develop their skills and abilities more (Nicholson, 1972). Dream and Doodle Books can be seen as a practical method that can be used by parents and teachers to develop creativity both at home and at school (Ryan, 2009).

It has been observed that children use their imaginations to re-narrate and reflect existing stimuli with the Dreams and Draw books, which are an example of creative activity. When children meet with creative practices and activities, they can use their existing potential and have opportunities to support their creative thinking skills. As 21st-century thinking skills, children need to think creatively, flexibly, critically, and analytically. To enable children to think flexibly and multi-dimensional from early childhood, they should be supported with different studies such as painting, story, game, and design (Torrance, 1975; Zelazo, Carlson, \& Kesek, 2008).

Different applications and programs that support the creative thinking skills of children are being developed and implemented both in the World and in Turkey. Dziedziewicz, Oledzka, Karwowski (2013), in their studies using the doodle-books program, concluded that these books improve the figural creativity of children between 
the ages of 4-6 and have an impact on the development of creative imagination and different thinking. In a different study, Garaigordobil, Berrueco (2011) showed that it is possible encouraging children's creative abilities from an early age.

As a result of many studies on creativity education (Sawyer, Tomlinson \& Maples, 2000; Graigner et al., 2004; Anderson \& Yates, 1999), it has been observed that children's creativity and multi-directional thinking skills can be developed with education and that after the education, their creativity characteristics such as fluency, originality and flexibility increase. Many researchers such as Esquivel (1995), Hocevar (1981), Reis, Burns, and Renzulli (1992) have argued that there is a link between creativity and effective teaching.

\section{Conflict of Interest Statement}

The author declares no conflicts of interests.

\section{About The Authors}

Arzu Akar Gençer is an assistant professor at Kırklareli University, in Health High School, Department of Child Development. She received a Ph.D. degree from Gazi University, in the Department of Child Development. She researches in the fields of creativity, drama education, children's rights especially child participation.

Abide Güngör Aytar is a professor at Gazi University, in the Department of Child Development. She researches in the fields of children's pictures, child mental health, child development, temperament.

\section{References}

Anderson A, Yates G.C.R, 1999. Clay modeling and social modeling: Effects of interactiveteaching on young children's creative art making. Educational Psychology, 19(4), 463-469.

Aral N, 2014. Yaratıcı Deneyimler. Çocuklarda Sanat ve Yaratıcılığın Gelişimi/Art \& Creative Development For Young Children, (Çev. Edit: Aral, N.ve G. Duman), 3263, Ankara: Nobel.

Aslan E, 2001. Torrance yaratıcı düşünce testinin Türkçe versiyonu. M.Ü. Atatürk Eğitim Fakültesi Eğitim Bilimleri Dergisi, 14, 19-40.

Aynal Ş. Ö, 2010. Eğitimde Yaratıcılık. Öncü, E. Ç. (Ed). Erken çocukluk döneminde yaratıcılık ve geliştirilmesi. Ankara: Pegem A. 100-109.

Bayındır N, İnan Z. H, 2008. Theory in topractice: Examination of teacher practices in supporting children's creativity and ceative thinking. Ozean Journal of Social Sciences 1(1).

Boudreau D. M, 2007. Narrative abilities in children with language impairments. In R. Paul (Ed.), Language disorders from a developmental perspective (pp. 331-356). Mahwah, NJ: Lawrence Erlbaum Associates. 
Catlow N, 2009. Oodles of doodles: Over 200 picturestocompleteandcreate. Philadelphia:Running Press Kids.

Christensen P, Prout A, 2002. Working with ethical symmetry in social research with children. Childhood, 9(4), 477-497.

Clark A, Moss P, 2001 Listening to young children: The mosaic approach. London: National Children's Bureau.

Davis G. A, Rimm S. B, 1985. Education of thegiftedandtalented. EnglewoodCliffs, NJ: PrenticeHall.

Dziedziewicz D. Oledzka, D.Karwowski M, 2013. Developing 4- to 6-year-old children'sfiguralcreativityusing a doodle-book program. Thinking Skills and Creativity 9, 85-95.

Garaigordobil M, Berrueco L, 2011. Effects of a play program on creative thinking of preschool children. Spanish Journal of Psychology, 14, 608-618.

Grainger T, Barnes J, Scoffham S, 2004. A creative cocktail: Creative teaching in initial teacher education. Journal of Education.

Guilford J. P, 1967. Thenature of human intelligence. New York: McGraw-Hill.

Isbell R \& Raines S. C, 2012. Creativity and thearts with young children. Cengage Learning.

Karnes M. B, McCoy G. F, Zehrbach R. R, Wollersheim J. P, Clarizio H. F, Costin L, Stanley L. S, 1961. Factors associated with under achievement and over achievement of intellectually gifted children. Champaign, IL: ChampaignCommunityUnit Schools.

Kindap Y, Sayıl M, 2005. Çocuk Çizimlerinde Temsil ve İfade: Doğrusal ve Doğrusal Olmayan Gelişim. Türk Psikoloji Dergisi, 20(56), 25.

Morrow V, Richards M, 1996. The ethics of social research with children: an overview. Children \&amp; society, 10(2), 90-105.

Miles M. B \& Huberman A. M, 1994. Qualitative data analysis: an expanded source book(2nd ed.). London: Sage.

Newcombe N. S, Frick A, 2010. Early education for spatial intelligence: Why, what and how. Mind, Brain \& Education, 4, 102-11.

Nicholson S, 1971. How Not To Cheat Children. TheTheory Of LooseParts. Landscape Architecture, 62(3), 3-34.

Pagani L, Rubenson D, Runco M. A, 2003. Theimpact of juniorkindergarten on behaviour in elementary school children. InternationelJournal of Behavioral Devolopment, 27(5), 423- 427. Rein, R. P, Rein, R. 2000. How can you improve yourchild's skills and abilities? S. Göktan(Trans.). İstanbul: Ya-pa.

Patton M. Quinn, 2014. Nitel Araştırma ve Değerlendirme Yöntemleri, 3. Baskıdan Çeviri, Patton, M. Q. “Qualitative Research and Evaluation Method”, Bütün, M. ve Demir, S. B (Ed), Pegem Yayınevi, Ankara.

Punch S, 2002. Research with children: The same or different from research with adults?. Childhood. 9(3), 321-41. 
Reis S. M, Burns D. E, Renzulli J. S, 1992. Curriculum Compacting: The complete guide to modifying the regular curriculum for high ability students. Mansfield Center, CT: Creative Learning Press.

Renzulli J. S, 1992. A general theory for the development of creative productivity through the pursuit of ideal acts of learning. Gifted Child Quarterly, 36, 170-182.

Runco A. M, 2004. Creativity. Annu. Rev. Psychol. 55:657-87 doi: 10.1146/annurev.psych.55.090902.141502.

Ryan N, 2009. Designer doodles: Over 100 designs to complete and create. Philadelphia: RunningPress Kids.

Sawyer A. J, Tomblinson S. R, Maples A. J, 2000. Developing Essentials Skillis through case study scenarios. Journal of Accounting Education, 18 (3), 257- 282.

Spyrou S, 2011. The limits of children's voices. From authencitiy to critical, reflexive representation. Childhood, 18 (2), 151-165.

Sternberg R. J, Lubart T. I, 1991. Creating creative minds. Phi Delta Kappan, 72, 608-614.

Tahiroğlu D, 2006. Hayal etmek çocuk işi! Çocukluk Döneminde Hayal Gücü. Ç. Aydın, T. Göksun, A. C. Küntay, D. Tahiroğlu (Eds). Aklın çocuk hali: zihin gelişimi araştırmaları. İstanbul: Küy.

Thorton L, Brunton P, 2009 Understanding the Reggio approach. Abingdon, Oxon: RoutledgePress.

Torrance E. P, Goff K, 1989. A Quiet Revolution. Journal of Creative Behavior. 23 (2), 136145.

Torrance E. P, 1972. Can we teach children to think creatively?Journal of Creative Behavior, 6, 114-143.

Woodhead M, 2004. Early childhood development: A question of rights. International.

Yıldırım A, Şimşek H, 2006. Sosyal bilimlerde nitel araştırma yöntemleri, (5. Baskı), Ankara: Seçkin Yayıncılık.

Zachopoulou E, Trevlas E, Konstadinidou E \& Archimedes Project Research Group, 2006. Thedesign an dimplementation of a physical education program to promote children's creativity in the early years. International Journal of Early Years Education, 14(3), 279-294.

Zelazo P D, Carlson S. M \& Kesek A, 2008. The development of executive function in childhood. MIT Press. 
Creative Commons licensing terms

Author(s) will retain the copyright of their published articles agreeing that a Creative Commons Attribution 4.0 International License (CC BY 4.0) terms will be applied to their work. Under the terms of this license, no permission is required from the author(s) or publisher for members of the community to copy, distribute, transmit or adapt the article content, providing a proper, prominent and unambiguous attribution to the authors in a manner that makes clear that the materials are being reused under permission of a Creative Commons License. Views, opinions and conclusions expressed in this research article are views, opinions and conclusions of the author(s). Open Access Publishing Group and European Journal of Education Studies shall not be responsible or answerable for any loss, damage or liability caused in relation to/arising out of conflicts of interest, copyright violations and inappropriate or inaccurate use of any kind content related or integrated into the research work. All the published works are meeting the Open Access Publishing requirements and can be freely accessed, shared, modified, distributed and used in educational, commercial and non-commercial purposes under a Creative Commons Attribution 4.0 International License (CC BY 4.0). 